GULF BREEZE, Fla.-Although genetically engineered plants have finally gone to field tests, efforts to field-test recombinant microbes remain stymied by opposition and regulatory delays.

The Environmental Protection Agency's Microbial Ecology and Biotechnology Branch here is trying to develop a genetic engineering tool that could greatly ease some public and governmental fears: a "suicide plasmid" whose genetic material falls apart when the organism completes its intended task.

The heart of the system, developed by EPA's Stephen Cuskey, consists of three genes and an inducible promot-

\section{FOR A 'SUICDE}

er. Cuskey's original design reflects EPA's interest in biodegrading toxic wastes. It contains a gene for an enzyme that degrades 3-chlorobenzoic acid, under control of a promoter that turns on when the substrate is present. Under control of the same promoter is a methylase gene. And nearby, but always on, is a gene producing a restriction enzyme (in this case EcoRI).

Thus, as long as the substrate is present, the gene is methylated-and is protected against the action of the restriction enzyme. When the target substrate is removed, however, methylation stops, and the restriction enzyme goes to work. This will kill a

\section{PLASMIN}

properly engineered organism and destroy the inserted plasmid. Neither the organism nor its genes can escape to areas beyond the substrate.

The idea could be extended to organisms that work on more common substrates. There, the promoter should be induced by a harmless, but rare, compound added to the local environment. When the inducer is used up or withdrawn, the microbe dices its own DNA and dies.

Whether the concept will actually work is still open to question; Cuskey did not expect to have a completed suicide plasmid ready until about the beginning of this month.

-Douglas McCormick

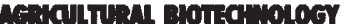

\section{MORE DICKERING O}

LONDON-Britain's last major independent seed company, Sinclair McGill, has been swallowed up by multinational giant, Imperial Chemical Industries (ICI, London) at a cost of $£ 5.1$ million. This occurs as staff at the National Seed Development Organisation (NSDO) and part of the associated Plant Breeding Institute (PBI, Cambridge) await news of their fate as the latest pawns to be moved out of public service under the Thatcher government's "privitization" strategy (see Bio/Technology 4:379, May '86).

ICI is also one of several eager suitors with their hats in the ring for the NSDO/PBI. With its take-over of the U.S. firm Garst last year for $\$ 60$ million, ICI has placed itself in a strong position to protect its huge fertilizer and insecticide businesses. In addition, ICI has announced that it hopes to take over further seed companies worldwide.

Sinclair McGill specializes in vegetable and cereal varieties and forage crops. Having successfully surrendered all of its fertilizer and seed interests, the parent company, William Sinclair Holdings, will now concentrate solely on the garden leisure sector, where it feels better able to compete. Almost all of Britain's other seed specialists are now in the hands of multinationals. Volvo, for example, controls Miln Masters, while Shell (which also wishes to acquire the NSDO/PBI) owns Nickersons.

Meanwhile, the merchant bank Lazards has completed its advisory report to the government on the privitization strategy, leaving ICI, Shell, and the other major contender, Agri-

\section{OVER BRITISH PLANT RESEARCH}

cultural Genetics Company (Cambridge, U.K.), wondering about the price they will be expected to pay. Several PBI researchers have already voted with their feet-by resigning in distaste over the privitization and the manner in which it became known to the staff.

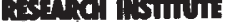 BRIAINS MRC FORMS NEW
MOLECULAR GENTICS UNIT}

CAMBRIDGE-On October 1 Sydney Brenner will exchange his post as director of the Medical Research Council (MRC) Laboratory of Molecular Biology for the directorship of a new Molecular Genetics Unit within MRC. Despite the financial hardship currently afflicting British science, MRC has found the funds to establish this first center of its sort, which will be devoted to the development and application of methods of gene mapping, the characterization of genes affecting the emergence of the nervous system in the nematode worm Caenorhabditis elegans, and certain aspects of gene evolution.

Announcing the appointment recently, MRC paid tribute to Brenner as one of the founding fathers of molecular biology "who was at one time or another involved with nearly every seminal discovery in the new field." In addition to working with $C$. elegans, which Brenner has already established as a powerful experimental system for analyzing gene function during morphogenesis, he intends to push forward with efforts to build up a physical map of the human genome. Considering recent proposals for all-out sequencing of the genome to be premature, Brenner believes instead that a physical map (constructed using methods he has developed with John Sulston) will afford much higher resolution and thus indicate specific domains of medical interest which can then be sequenced comparatively quickly.

When Brenner relinquishes his present appointment, Aron Klug will take over as director of the MRC Laboratory of Molecular Biology, which will continue its existing work on the structures of proteins, nucleic acids, and macromolecular assemblies. His wide portfolio of interests includes the assembly and molecular architecture of viruses, the structure of chromatin and transfer RNA, and the refinement of investigative techniques such as X-ray diffraction. As Klug's research output remains as vigorous as ever at the age of 60 , MRC has taken the unprecedented step of announcing that he should continue as director of the Cambridge lab until he reaches 67 . At a time when many U.K. scientists are being invited to take early retirement, this represents an accolade that almost rivals the Nobel Prize for chemistry that he received in 1982 . - BD 